\title{
A study protocol for the evaluation of occupational mutagenic/carcinogenic risks in subjects exposed to antineoplastic drugs: a multicentric project
}

Massimo Moretti ${ }^{1}$, Roberta Bonfiglioli ${ }^{2}$, Donatella Feretti ${ }^{3}$, Sofia Pavanello ${ }^{4}$, Francesca Mussi ${ }^{5}$, Maria G Grollino ${ }^{6}$, Milena Villarini ${ }^{1}$, Anna Barbieri ${ }^{2}$, Elisabetta Ceretti ${ }^{3}$, Mariella Carrieri ${ }^{4}$, Annamaria Buschini ${ }^{5}$, Massimo Appolloni ${ }^{6}$, Luca Dominici ${ }^{1}$, Laura Sabatini ${ }^{2}$, Umberto Gelatti ${ }^{3}$, Giovanni B Bartolucci ${ }^{4}$, Paola Poli ${ }^{5}$, Laura Stronati ${ }^{6}$, Giuseppe Mastrangelo ${ }^{4}$ and Silvano Monarca ${ }^{1 *}$

\begin{abstract}
Background: Some industrial hygiene studies have assessed occupational exposure to antineoplastic drugs; other epidemiological investigations have detected various toxicological effects in exposure groups labeled with the job title. In no research has the same population been studied both environmentally and epidemiologically. The protocol of the epidemiological study presented here uses an integrated environmental and biological monitoring approach. The aim is to assess in hospital nurses preparing and/or administering therapy to cancer patients the current level of occupational exposure to antineoplastic drugs, DNA and chromosome damage as cancer predictive effects, and the association between the two.

Methods/Design: About 80 healthy non-smoking female nurses, who job it is to prepare or handle antineoplastic drugs, and a reference group of about 80 healthy non-smoking female nurses not occupationally exposed to chemicals will be examined simultaneously in a cross-sectional study. All the workers will be recruited from five hospitals in northern and central Italy after their informed consent has been obtained.

Evaluation of surface contamination and dermal exposure to antineoplastic drugs will be assessed by determining cyclophosphamide on selected surfaces (wipes) and on the exposed nurses' clothes (pads). The concentration of unmetabolized cyclophosphamide as a biomarker of internal dose will be measured in end-shift urine samples from exposed nurses.

Biomarkers of effect and susceptibility will be assessed in exposed and unexposed nurses: urinary concentration of 8-hydroxy-2-deoxyguanosine; DNA damage detected using the single-cell microgel electrophoresis (comet) assay in peripheral white blood cells; micronuclei and chromosome aberrations in peripheral blood lymphocytes. Genetic polymorphisms for enzymes involved in metabolic detoxification (i.e. glutathione S-transferases) will also be analysed.

Using standardized questionnaires, occupational exposure will be determined in exposed nurses only, whereas potential confounders (medicine consumption, lifestyle habits, diet and other non-occupational exposures) will be assessed in both groups of hospital workers.

Statistical analysis will be performed to ascertain the association between occupational exposure to antineoplastic drugs and biomarkers of DNA and chromosome damage, after taking into account the effects of individual genetic susceptibility, and the presence of confounding exposures.
\end{abstract}

Discussion: The findings of the study will be useful in updating prevention procedures for handling antineoplastic drugs.

\footnotetext{
* Correspondence: monarca@unipg.it

'Department of Medical-Surgical Specialties and Public Health, University of

Perugia, Via del Giochetto, 06122 Perugia, Italy

Full list of author information is available at the end of the article
} 


\section{Background}

The occupational risk of environmental contamination during the storage, reconstitution, administration of antineoplastic drugs and the elimination of residues is well documented [1-4]. The chemical and physical properties of the drug, the quantity administered, the availability of personal and collective protection devices and the worker's skill determine the level of antiblastic contamination.

Several studies carried out at hospital units have shown detectable levels of cytotoxic agents in the air [5-7], on surfaces [8-15], on gloves [8,14], and on different parts of the body $[7,8,16]$. Biological monitoring methods have been developed to detect occupational exposure to antineoplastic agents [17]. The presence of these drugs in the urine of hospital personnel has been widely studied $[7,9,18-20]$. This has lead several organizations to develop guidelines or recommendations with the aim to improve safety during the handling of antineoplastic drugs and reduce risk of contamination in the workplace [21-23]. Based on these findings, guidelines have been also published in Italy [24].

Many anticancer agents have the potential to cause genetic alterations, which may lead to the development of cancer if they occur in proto-oncogenes or tumoursuppressor genes, which are involved in controlling cell growth or differentiation [25]. Accordingly, several antineoplastic drugs have been classified by the International Agency of Research on Cancer (IARC), on the basis of epidemiological reports, animal carcinogenicity data, as well as the outcomes of in vitro genotoxicity studies, as definite (Group 1), probable (Group 2A) or possible (Group 2B) human carcinogens [26-29].

Although health care workers are exposed to much lower doses than cancer patients are, low-dose exposure over long periods can have long-term health effects.

Several epidemiological studies have been conducted investigating the cancer risks of nurses exposed to antineoplastic drugs. Increased risks for leukaemia and breast cancer were reported by Skov et al. [30] and Gunnarsdottir et al. [31]. In a more recent research article, Ratner et al. [32] performed a cohort study among over 56,000 Canadian female nurses from British Columbia and concluded that subjects potentially exposed to antineoplastic drugs through their employment had an elevated risk of breast and rectal cancer.

Following environmental monitoring studies on contamination of workplaces from antineoplastic drugs, several biological monitoring studies have been performed. A number of studies indicate that antineoplastic drugs may cause increased genotoxic effects in pharmacists and nurses exposed in the workplace.

Undeger et al. [33] reported a significantly higher frequency of DNA damage - analysed using the alkaline single cell gel electrophoresis technique (comet assay) in lymphocytes of nurses handling antiblastic drugs compared to unexposed controls; the DNA damage was, however, found to be significantly lower in nurses using compulsory personal protection equipment during their work. 8-hydroxy-2'-deoxyguanosine (8OHdG) - presumed to be an expression of oxidative damage to DNA - has never been used in assessing the mutagenic risk of occupational exposure to antineoplastic drugs.

Chromosome aberration (CA) frequencies in patients undergoing chemotherapy were significantly higher than in controls [34-37]. Increased CA frequencies have also been found in hospital personnel handling cytotoxic drugs [18,38-43]. Negative findings have also been reported, however [44-47]. In hospitals where nurses used inadequate safety cabinets when handling cytostatics, significantly elevated levels of CAs (as well as sister chromatid exchanges, SCEs, and unscheduled DNArepair synthesis) were detected by Jakab et al. [48].

According to Kevekordes et al. [49], a malfunctioning safety hood resulted in a higher frequency of micronuclei $(\mathrm{MN})$ and SCE in exposed nurses compared to matched controls. Kasuba et al. [50] found that the length of handling cytostatic drugs increased the frequency of $\mathrm{MN}$, whereas no statistically significant difference was observed for SCE. In hospital pharmacy personnel adopting high standards of safety, Pilger et al. [51] observed that frequencies of MN and SCE were similar to those of controls, whereas small increases in these genetic end-points were found in accidental contamination events. Anwar et al. [43] found statistically significant increases in both CAs and $\mathrm{MN}$ in nurses handling cytostatic drugs. Hessel et al. [52] reported no association between antiblastic drugs in urine and $\mathrm{MN}$ frequency in lymphocytes of exposed hospital workers. Lastly, Maluf \& Erdtmann [53], when comparing pharmacists and nurses exposed to antineoplastic drugs with unexposed controls, found no statistical difference for $\mathrm{MN}$ and dicentric bridge frequency, whereas the mean value of DNA migration detected by comet assay was significantly higher in the exposed group compared to the controls.

Several studies showed the influence of metabolic and DNA repair polymorphisms on biological indicators of genotoxic risk (urinary metabolites, protein and DNA adducts, citogenetic tests), which are commonly used in the biomonitoring of occupational exposure to antineoplastic agents [54]. There are however few studies on the influence of genetic polymorphisms of enzymes involved in DNA damage induced by occupational exposure to antineoplastic drugs $[55,56]$.

In conclusion, some chemical studies have assessed occupational exposure to antineoplastic drugs, and some epidemiological investigations have detected various 
toxicologic effects in groups of exposed workers. To our knowledge, only very few researches have studied the same population by simultaneous assessment of exposure, biologic effects and genetic susceptibility [57].

The protocol of this molecular epidemiology study therefore presents an integrated chemical and biotoxicological approach for environmental and biological monitoring of exposure and cancer risks which will be implemented in a large number of healthy non-smoking female hospital nurses. This approach is based on monitoring procedures reported on the Italian guidelines [24] which includes, beside methods for preventing exposure to antineoplastic drugs, also monitoring recommendations. In particular, the guidelines provides guidance on the control of antineoplastic drug contaminations on surfaces and clothes by environmental monitoring (wipe and pad tests, respectively) and on the control of exposure by biological monitoring (concentrations of antineoplastic drugs in body fluids, usually urine), with both contamination and exposure depending on working practices and the frequency and adequacy of decontamination procedures. In this context, the advantage of biological monitoring is being able to measure the total uptake of antineoplastic drugs by all routes of exposure, however, testing is generally limited to one or very few agents that are considered as model compounds. In this study, monitoring of genotoxic risks we will performed by combining environmental and biological monitoring as above, with procedures for biological effect monitoring (urinary $8 \mathrm{OHdG}$, DNA strand breakage and cytogenetic abnormalities in lymphocytes) as well as genetic susceptibility monitoring (metabolic polymorphisms).

\section{Study objectives}

The aim of this study is to assess:

- the level of exposure to antineoplastic drugs (concentrations of substances in the working environment and on clothes; levels of biomarkers of exposure in endshift urine) in nurses preparing and administering antineoplastic drugs;

- the profile of DNA and chromosome damage (cytogenetic and DNA primary alterations) and genetic polymorphisms in the same nurses preparing and/or administering therapy to cancer patients and in a control group of unexposed nurses;

- the association between exposure and genetic damage, taking into account the confounding effects of non-occupational exposures and the modulating effects of genetic polymorphisms.

Among the several biotoxicological tests that will be performed, the frequency of micronuclei (MN) and chromosome aberrations (CA) in peripheral lymphocytes are recognized to be predictors of cancer risks in human populations $[58,59]$.

\section{Methods/Design}

The proposed epidemiological study will be carried out following the integrated environmental and biological monitoring approach shown in Figure 1.

\section{Population recruitment}

The study will be conducted on about 80 healthy nonsmoking female nurses whose job it is to prepare and administer antineoplastic drugs. Workers will be recruited on a voluntary basis from five hospital departments in northern and central Italy. A reference group of about 80 healthy non-smoking female nurses - working in the same hospitals but not occupationally exposed to antineoplastic drugs, comparable for age and lifestyle habits - will be sampled and examined in parallel with the exposed group. Exclusion criteria will be male gender, active smoking, and radiography, radiotherapy or chemotherapy in the past 12 months.

An informed consent form will be signed by each worker included in the study.

\section{Sample collection}

Work-shift urine samples will be collected from the workers in the investigated workplaces. Urine will be continuously collected 4 hours after the beginning until the end of the work-shift. During the same sampling session, end-shift blood samples will be collected taken by venipuncture and collected in heparinized or lithium EDTA vacuum tubes, for cytogenetic analyses or genotyping, respectively [60-62].

\section{Questionnaires}

A questionnaire regarding the work environment will be designed to gather information from the ward sister on key characteristics of each hospital ward, namely: details of the preparation area (hood: type, discharge type, coverage plan, inlet and outlet filters, filters replacement and cleaning procedures), as well as conditions in the preparation and administration areas (appropriate space, exclusive use, access restrictions; presence of warning signs, dressing room, sinks, eyewash, shower; adequate lighting and ventilation, microclimate conditions; waterproof uniform intact floor and walls).

Trained interviewers will collect information from each subject by means of three other standardized questionnaires (A, B, and $\mathrm{C}$ ).

Questionnaire A, which will be administered to both exposed and unexposed nurses, investigate personal details (age, height and weight), previous and present diseases, lifestyle habits (diet, passive smoking, alcohol and medicine consumption, physical activity and other leisure activities), and non-occupational exposures to mutagenic and carcinogenic agents, such as polycyclic 


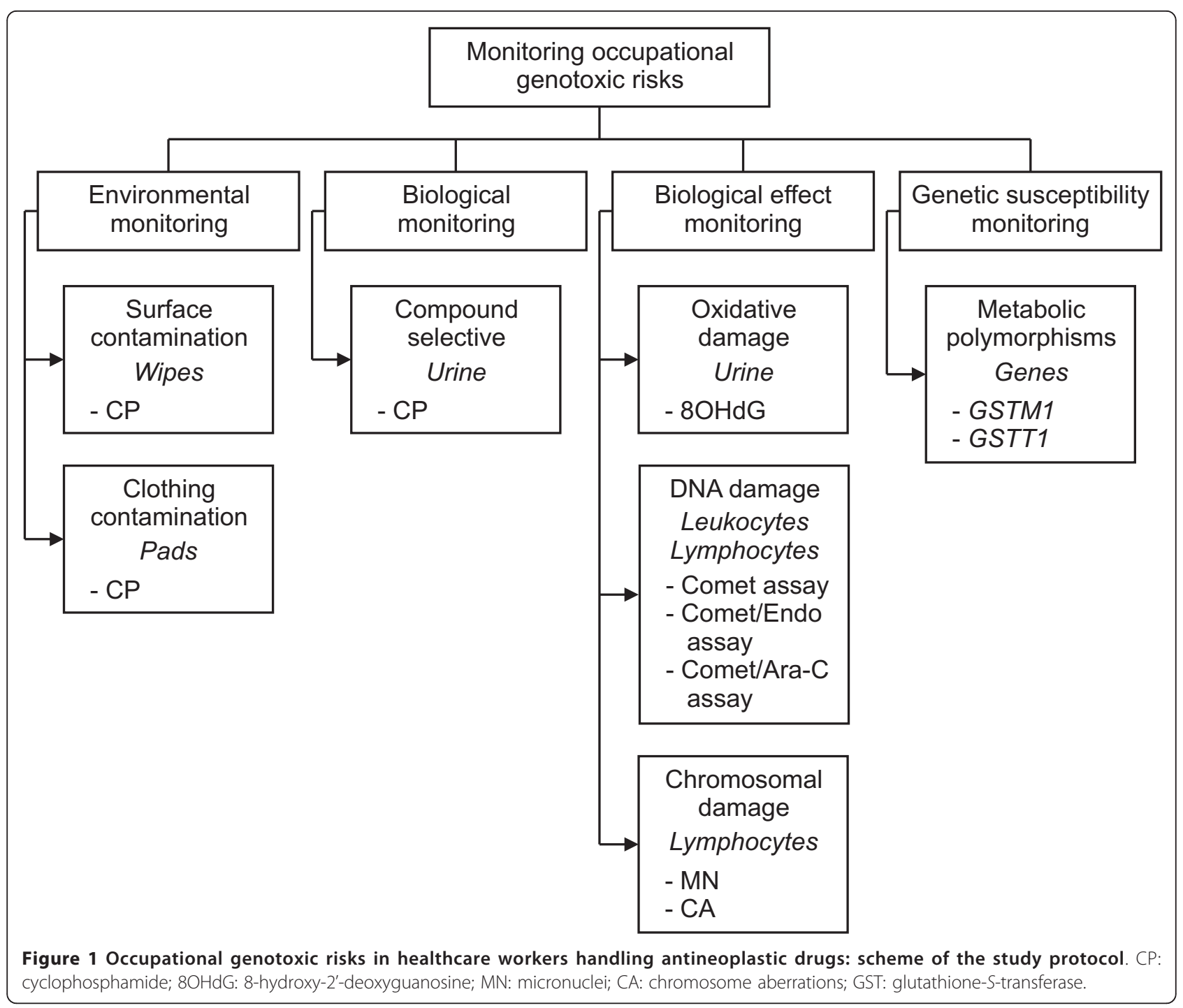

aromatic hydrocarbons (PAH) present in diet (weekly consumption of charcoaled and/or smoked meat), indoor (use of wood or coal to heat the home) and outdoor environment (residence close to intense traffic and/or factories) [61,63].

Questionnaires B and C, which will be administered to exposed nurses only, investigate work experience and occupational exposures. Emphasis will be placed on gathering the following information:

- hospital ward, years of service, length of exposure for each task (preparation or administration of cytostatic drugs, patient care, waste disposal) performed during a typical work-shift;

- antineoplastic drug exposure: names of cytostatics most frequently handled in the previous 12 months (questionnaire B); names and quantities of cytostatics handled during the last two workshifts (questionnaire C);
- safety measures adopted by each worker (use of personal protection equipment, PPE; hand washing frequency; other).

\section{Environmental monitoring of exposure}

Chemical analysis of the environmental samples will be carried out by determining the concentration of cyclophosphamide (CP), the marker of exposure to antineoplastic drugs according to established guidelines [24]. $\mathrm{CP}$ concentration will be determined in the work environment by using two techniques:

- surface removal technique (wipe-test);

- pad technique, to evaluate the contamination of exposed nurses' clothes.

\section{Wipe test}

The wipe sampling procedure will be performed according to the method of Sessink et al. [64], modified [65]. 
The technique involves cleaning a standard surface measuring $15 \times 15 \mathrm{~cm}\left(225 \mathrm{~cm}^{2}\right)$ thoroughly using a set of folded wipes (non-woven disposable material) wetted with $2 \mathrm{ml}$ of $0.03 \mathrm{M} \mathrm{NaOH}$ solution. The standard sampling sites will be located on the hood surface (preparation site) or the drip surface (administration site). Blank wipes will also be tested. New gloves will be used for each collected wipe sample to prevent cross-contamination. The wipes will be put in test-tubes and transferred to the laboratory. Subsequently, $18 \mathrm{ml}$ of $0.03 \mathrm{M} \mathrm{NaOH}$ solution will be added. The samples will be stirred for 10 minutes, sonicated for 30 minutes, centrifuged at $3000 \mathrm{rpm}$ for 20 minutes and stored at $-20^{\circ} \mathrm{C}$ until analysis.

The analysis will be carried out with GC-MS/MS. Briefly, a $1 \mathrm{ml}$ of sample will be added with $100 \mu \mathrm{l}$ of ifosfamide (IS) as internal standard. The solution will be put in a cartridge containing diatomaceous heart and the analytes eluted with $5 \mathrm{ml}$ of ethyl acetate (twice). Organic layers will be combined and dried in a vacuum centrifuge. The residue will be dissolved in $100 \mu \mathrm{l}$ of ethyl acetate and the CP and IS will be derivatized by adding $50 \mu \mathrm{l}$ of trichloroacetic anhydride at $70^{\circ} \mathrm{C}$ for 30 minutes. The solvent will be evaporated in a vacuum centrifuge, and the residue will be dissolved in $50 \mu \mathrm{l}$ of toluene and analysed in GC-MS/MS.

\section{Pad test}

The pad technique - widely used for monitoring xenobiotics [5] - will be used to evaluate contamination of clothes of nurses exposed to antineoplastic drugs. A pad of non-woven disposable material will be applied to clothes of the left forearm (non-dominant arm) of each subject during the working shift. The pad will be dampened with $1 \mathrm{ml}$ of $0.03 \mathrm{M} \mathrm{NaOH}$ solution. The pads will be recovered at the end of the shift, placed in testtubes and transferred to the laboratory, where they will be treated according to the procedure used for the wipe-tests.

On the whole, 1 wipe test (hood surface) and 1 pad test (left forearm) will be performed for each worker preparing antineoplastic drugs; 1 wipe test (drip surface) and 1 pad test (left forearm) will be carried out for each worker administering the drugs.

\section{Biological monitoring of exposure}

To allow a better evaluation of exposure, a biomarker of internal dose (CP) will be measured in end-shift urine samples using an analytical method developed by Barbieri et al. [66]. Urine samples will be collected from the exposed workers during days that $\mathrm{CP}$ is handled.

The analysis will be performed by liquid chromatography coupled with a triple-quadrupole mass spectrometer equipped with an electrospray source (LC-ESI-MS/MS) after urine sample purification and concentration using solid phase extraction (SPE). Mass spectrometric detection increases sensitivity, and multiple-reaction-monitoring (MRM) acquisition mode leads to high specificity (i. e. the limit of detection is $0.04 \mu \mathrm{g} / \mathrm{l}$ urine for CP). Another aim of the study will be also to improve the sensitivity of the above method using a micro-HPLC, with lower flows $(10 \mu \mathrm{l} / \mathrm{min}$ versus $200 \mu \mathrm{l} / \mathrm{min}$ for conventional HPLC) and smaller sample volumes $(0.5 \mu \mathrm{l}$ versus $20 \mu \mathrm{l})$.

\section{Biomarkers of DNA and chromosome damage}

The biomarkers of DNA damage will be assessed in exposed and unexposed nurses.

\section{Urinary concentration of $80 \mathrm{HdG}$}

$\mathrm{T}$ he determination of urinary 8-hydroxy-2-deoxyguanosine ( $8 \mathrm{OHdG}$ ) will be determined in both study groups, i.e. workers exposed and not exposed to antineoplastic drugs. The method, validated by Sabatini et al. [67], is based on high-performance capillary liquid chromatography coupled with an electrospray source with tandem mass spectrometric detection (micro-HPLC-ESI-MS/ MS). Urine samples will be collected and extracted using Isolute Env+ SPE cartridges, and $0.5 \mu \mathrm{l}$ of this extract will undergo micro-HPLC-ESI-MS/MS. MS/MS analysis will be conducted in positive ion mode and acquisition will be performed in MRM mode, selectively monitoring the typical transition of 8OHdG.

\section{Comet Assay}

To assess primary DNA damage under alkaline conditions, the single-cell microgel electrophoresis (comet) assay $[68,69]$ will be performed on peripheral blood leukocytes of exposed and control nurses [60,70-72]. For slide preparation, $10 \mu \mathrm{l}$ aliquots of heparinized blood will be mixed with $100 \mu$ l low-melting-point agarose (0.7\% in PBS) and layered onto pre-treated conventional slides. After overnight lysis $\left(+4^{\circ} \mathrm{C}\right)$ in alkaline buffer $(\mathrm{pH}$ 10) of cellular and nuclear membranes, the slides will be placed in a horizontal electrophoresis box, allowed to unwind for $20 \mathrm{~min}$ in an electrophoretic alkaline buffer $(\mathrm{pH}>13)$ and then subjected to electrophoresis $\left(+4^{\circ} \mathrm{C}\right)$ for $20 \mathrm{~min}$ by applying an electric field of $1 \mathrm{~V} / \mathrm{cm}$ and adjusting the current to $300 \mathrm{~mA}$. Lastly, the microgels will be neutralized and stained with ethidium bromide. To evaluate DNA damage, the slides will be examined using an epi-fluorescence microscope equipped with a high-sensitivity CCD (charge-coupled device) camera connected to a computerized image analysis system. Computerized imaging will be performed on coded slides using dedicated software which estimates damage parameters (i.e. tail length, tail intensity and tail moment) by comet profile [73]. Two hundred cells will be analysed for each subject (100 cells/slide, 2 slides per subject). Since the three research units examining DNA damage will use different computerized analysis systems, 
intercalibration tests will be performed to standardize the procedures used for DNA migration evaluation. For this purpose, the extent of DNA migration will also be evaluated by "visual scoring" based on visual classification of DNA damage.

\section{Comet/Endo-III assay (DNA oxidative damage)}

DNA oxidative damage will be evaluated in peripheral blood lymphocytes with a modification of the standard comet assay using enzymes of the excision repair system [74]. Endonuclease III (Endo-III) recognizes and cuts oxidized bases, mostly pyrimidines $[75,76]$. When this enzyme nicks DNA at sites of oxidatively damaged nucleotides, it creates single-strand breaks(SSB) detectable using the alkaline comet assay. For slide preparation, freshly collected white blood cells will be included in agarose microgels as described for the standard comet assay. After the lysis step, the microgels will be incubated with Endo-III for $60 \mathrm{~min}$ at $37^{\circ} \mathrm{C}$. The slides will undergo alkaline electrophoresis (30 min unwinding and $20 \mathrm{~min}$ electrophoresis) and then stained as described for the standard comet assay. To evaluate DNA damage, the slides will be examined as described above for the standard procedure of the comet assay.

\section{Comet/Ara-C assay}

A modified protocol that uses a DNA repair inhibitor has been proposed as a means for increasing the sensitivity of the assay [77]. In particular, lymphocyte incubation with cytosine arabinoside (Ara-C) inhibits DNA resynthesis during nucleotide excision repair and under standard experimental conditions transforms 'cryptic' lesions into SSB detectable with the alkaline comet assay. The evaluation of DNA damage to cells treated with Ara-C will be performed on peripheral blood lymphocytes isolated from whole blood samples using polysucrose density-gradient. The lymphocytes will be resuspended in RPMI-1640 medium and cultured for $16 \mathrm{~h}$ in the presence or the absence of Ara-C $(1 \mu \mathrm{g} / \mathrm{ml})$ [78]. At the end of the culture time the cells will be washed and harvested by centrifugation, and the pellets will be mixed with low-melting-point agarose, subjected to alkaline lysis and electrophoresis, and stained and analysed as described for the standard comet assay.

\section{Cytokinesis-block micronucleus test}

All the subjects (exposed and controls) will be tested for the presence of $\mathrm{MN}$ in lymphocytes. Cell cultures will be set up by adding $0.3 \mathrm{ml}$ of whole blood to $4.7 \mathrm{ml}$ of RPMI-1640 medium supplemented with $20 \%$ foetal calf serum, $2 \mathrm{mM} L$-glutamine, $2 \%$ phytohaemoagglutinin and penicillin-streptomycin $(100 \mathrm{IU} / \mathrm{ml}$ e $100 \mu \mathrm{g} / \mathrm{ml}$, respectively). Whole blood cultures will be incubated for $72 \mathrm{~h}$ at $37^{\circ} \mathrm{C}, 5 \% \mathrm{CO}_{2}$ [79]. To have binucleated cells, cytochalasin B (final concentration $3 \mu \mathrm{g} / \mathrm{ml}$ ) will be added after $44 \mathrm{~h}$ [80]. The cells will then be collected by centrifugation, re-suspended in a pre-warmed hypotonic solution $(75 \mathrm{mM} \mathrm{KCl})$ for $15 \mathrm{~min}$ at $37^{\circ} \mathrm{C}$ and fixed in acetic acid - methanol (1:5 v:v). Air-dried preparations will be stained with $4 \%$ Giemsa. For cytogenetic analysis, a total of 1000 binucleated lymphocytes with preserved cytoplasm will be scored for each subject. MN evaluation will be based on standard criteria [81].

\section{Chromosome aberration test}

The entire population of enrolled subjects will also be tested for the presence of CA. Cell cultures will be set up by adding $0.5 \mathrm{ml}$ of whole blood to $4.5 \mathrm{ml}$ of RPMI-1640 medium supplemented with $10 \%$ foetal calf serum, $2 \%$ phytohaemoagglutinin and $1.5 \%$ penicillinstreptomycin. Whole blood will be cultured at $37^{\circ} \mathrm{C}$, $5 \% \mathrm{CO} 2$, following 90 minutes treatment with $0.2 \mu \mathrm{g} /$ $\mathrm{ml}$ colcemid. 5-Bromodeoxyuridine will be added at a final concentration of $10 \mu \mathrm{g} / \mathrm{ml}$. Cultures will be fixed at $48 \mathrm{~h}$ according to standard protocol [82]. Air-dried metaphase spreads will be stained according to the conventional unbanded Giemsa method. For cytogenetic analysis, an average of 100 well-spread metaphases per subject will be examined by optical microscopy. The analysis of CA will be performed only on cells with 46 chromosomes $(+/-1)$. CA will classified on the basis of standard criteria [83]. Both chromosome- and chromatid-type aberrations will be scored. Chromosome and chromatid breaks will be distinguished from gaps according to their break size and morphology.

\section{Biomarkers of genetic polymorphisms}

Genetic polymorphisms for enzymes involved in metabolic detoxification (GSTM1 and GSTT1) will be analysed in exposed and unexposed nurses.

\section{Genotype analysis}

DNA from peripheral blood leucocyte (PBL) pellets will be isolated with a Promega Wizard genomic DNA purification kit (Promega, Italy). As described previously [84], the procedure will provide DNA free of RNA and protein contamination. A multiplex PCR method will be used to detect the presence or absence of the GSTM1 and GSTT1 genes, according to the protocol described previously [85]. This PCR method presents both GSTM1- and GSTT1-specific primer pairs in the same amplification mixture and includes a third primer pair for $\beta$-globin as an internal positive PCR control. The GSTT1 (480 bp), $\beta$-globin (285 bp), and GSTM1 (215 bp) amplification products will be resolved in an ethidium bromide-stained 2\% agarose gel. The absence of the GSTM1- or GSTT1-specific fragment indicates the corresponding null genotype $\left({ }^{*} 0 /{ }^{*} 0\right)$, whereas the $\beta$-globin-specific fragment confirms the presence of amplifiable DNA in the reaction mixture. Quality control measures will be adopted for validation of results using RT-PCR and blind repeat of $10 \%$ of samples. 


\section{Statistical analysis}

Statistical analysis will be performed to determine the association between occupational exposure to antineoplastic drugs (evaluated by environmental and biological monitoring) and biomarkers of DNA and chromosome damage, taking into consideration the effect of genetic polymorphisms, the safety procedures adopted, and confounding exposures of non-occupational origin.

The required sample size for the comparison of means from two independent samples was estimated assuming:

- the means and standard deviations reported in literature for DNA damage detected using the single-cell microgel electrophoresis (comet) assay in peripheral white blood cells, MN and CA in peripheral blood lymphocytes;

- a type I error rate of 0.05 and a power of 0.80 .

Using the module "sampsi" of STATA 10 statistical software, the minimum sample size was of 47 exposed and 47 control nurses. The actual sample will be enlarged to include 80 individuals in each sample, to take also account of the number of predictors in the multiple regression analysis.

\section{Ethical approval}

The study protocol has been firstly approved by the Ethics Committee of Health Institutions of Umbria Region (CEAS, Comitato Etico delle Aziende Sanitarie della Regione Umbria), Perugia and then by the other regional ethics committees (Comitato Etico dell'Azienda Ospedaliero-Universitaria di Bologna, Policlinico Sant'Orsola-Malpighi, Bologna; CEIOC, Comitato Etico Istituzioni Ospedaliere Cattoliche, Brescia; Comitato di Etica dell'Università degli Studi di Parma, Parma).

\section{Discussion}

In a cross-sectional design such as ours, the prevalence of a disease is measured in relation to its determinants. Prevalence is a composite parameter, which depends on the incidence rate, the rate of cure, the fatality rate, and the duration of the disease. In addition, in studies of occupational epidemiology, health-selective turnover may further distort the information contained in the prevalence rate.

A follow-up of the study base - an incidence study - is better suited to solving etiologic problems than a crosssectional one. The incidence of a disease is usually more informative than its prevalence, and incidence studies require a longitudinal design in which exposure and outcome are measured at different points in time.

Although cross-sectional designs have no time dimension, they can sometimes provide etiologic information. One example is the study of diseases with short or no latency, such as respiratory symptoms caused by irritant gases.
This study comprises short-term risk factors (names and quantities of cytostatics handled during the last two workshifts, collected on questionnaire $\mathrm{C}$; $\mathrm{CP}$ in urine) and short-term response indicators (DNA strand breaks in polymorphonuclear leukocytes which have a lifetime of few hours to few days, as well as urinary $8 \mathrm{OHdG}$ ). It should be noted that questionnaire $C$ will be filled in the same day on which urine (for CP concentration) and blood (for comet assay) will be collected. We will therefore be able to determine whether there is an etiological association between occupational exposure to cytostatics and DNA damage.

This study also includes medium-term changes (cytogenetic abnormalities in lymphocytes which have a lifetime of weeks to years). AC and MN are of particular importance for prevention, since recent epidemiological studies have demonstrated the predictive value of carcinogenic risks from these two biomarkers [58,59].

The difference between exposed and unexposed nurses with regard to changes in short-term response (comet assay) could be less evident than that concerning medium-term effects ( $\mathrm{AC}$ and $\mathrm{MN}$ ). These results would indicate overall working conditions less satisfactory or safe in the past than in current conditions.

Any association between $\mathrm{CP}$ contamination and the use of PPE and number of preparations/day could potentially suggest useful information for prevention: an increase in health education if contamination is found to increase with relaxed rules of prevention, or a decrease in the workload if the number of applications is found to conflict with the level of prevention.

Both short-term and medium-term indicators of DNA damage are non-specific responses which depend on several risk factors of occupational and non-occupational origin. In order to prevent confounding, it has been decided to focus on one category of nurses, only female nurses declaring themselves to be long-life non-smokers. There are also other restrictions (see exclusion criteria in Methods). This choice requires the number of hospitals involved to be increased to 5 in order to achieve a sample size with sufficient statistical power. Restriction alone is a weak method for controlling confounding, and this can only be achieved by proper statistical analysis. Therefore, in order to control for non-occupational confounders, we have devised questionnaire A to gain information on a large number of potential risk factors.

\section{Acknowledgements}

The study is funded by the Italian Ministry of Education, University and Scientific Research (MIUR), Research No. 2005-062547 (Prof. Silvano Monarca: National Coordinator of the multicentric study).

\section{Author details}

${ }^{1}$ Department of Medical-Surgical Specialties and Public Health, University of Perugia, Via del Giochetto, 06122 Perugia, Italy. ${ }^{2}$ Department of Internal 
Medicine, Geriatrics and Nephrology, Section of Occupational Medicine Alma Mater Studiorum, Sant'Orsola-Malpighi Hospital, University of Bologna, Via Palagi 9, 40138 Bologna, Italy. ${ }^{3}$ Department of Experimental and Applied Medicine, Hygiene Section, University of Brescia, Viale Europa 11, 25123 Brescia, Italy. ${ }^{4}$ Department of Environmental Medicine and Public Health, University of Padova, Via Giustiniani 2, 35128 Padova, Italy. ${ }^{5}$ Department of Genetics, Biology of Microrganisms, Anthropology, Evolution, University of Parma, Parco Area delle Scienze 11A, 43124 Parma, Italy. ${ }^{6}$ Unit of Radiation Biology and Human Health, ENEA CR Casaccia, Via Anguillarese 301, 00123 Rome, Italy.

\section{Authors' contributions}

The authors contributed equally to this work. All authors have taken part in the academic discussions of the manuscript's content, in drafting the article and in revising it. All authors have approved the final version.

\section{Competing interests}

The authors declare that they have no competing interests.

Received: 9 February 2011 Accepted: 30 March 2011

Published: 30 March 2011

\section{References}

1. Connor TH, McDiarmid MA: Preventing occupational exposures to antineoplastic drugs in health care settings. CA Cancer J Clin 2006, 56:354-365.

2. Kiffmeyer T, Hadtstein C: Handling of chemotherapeutic drugs in the OR: hazards and safety considerations. Cancer treatment and research 2007, 134:275-290

3. Turci R, Minoia C: Residual hazard assessment related to handling of antineoplastic drugs: safety system evolution and quality assurance of analytical measurement. Annals of the New York Academy of Sciences 2006, 1076:649-656

4. Turci R, Sottani C, Spagnoli G, Minoia C: Biological and environmental monitoring of hospital personnel exposed to antineoplastic agents: a review of analytical methods. Journal of Chromatography B, Analytical Technologies in the Biomedical and Life Sciences 2003, 789:169-209.

5. McDevitt JJ, Lees PS, McDiarmid MA: Exposure of hospital pharmacists and nurses to antineoplastic agents. J Occup Med 1993, 35:57-60.

6. Pyy L, Sorsa M, Hakala E: Ambient monitoring of cyclophosphamide in manufacture and hospitals. American Industrial Hygiene Association journal 1988, 49:314-317.

7. Sessink PJ, Cerna M, Rossner P, Pastorkova A, Bavarova H, Frankova K, Anzion RB, Bos RP: Urinary cyclophosphamide excretion and chromosomal aberrations in peripheral blood lymphocytes after occupational exposure to antineoplastic agents. Mutation research 1994, 309:193-199.

8. Minoia C, Turci R, Sottani C, Schiavi A, Perbellini L, Angeleri S, Draicchio F, Apostoli P: Application of high performance liquid chromatography/ tandem mass spectrometry in the environmental and biological monitoring of health care personnel occupationally exposed to cyclophosphamide and ifosfamide. Rapid Commun Mass Spectrom 1998, 12:1485-1493.

9. Sessink PJ, Boer KA, Scheefhals AP, Anzion RB, Bos RP: Occupational exposure to antineoplastic agents at several departments in a hospital. Environmental contamination and excretion of cyclophosphamide and ifosfamide in urine of exposed workers. International archives of occupational and environmental health 1992, 64:105-112.

10. Floridia L, Pietropaolo AM, Tavazzani M, Rubino FM, Colombi A: Highperformance liquid chromatography of methotrexate for environmental monitoring of surface contamination in hospital departments and assessment of occupational exposure. Journal of chromatography 1999, 726:95-103.

11. Floridia L, Pietropaolo AM, Tavazzani M, Rubino FM, Colombi A: Measurement of surface contamination from nucleoside analogue antineoplastic drugs by high-performance liquid chromatography in occupational hygiene studies of oncologic hospital departments. Journal of chromatography 1999, 724:325-334.

12. Connor TH, Anderson RW, Sessink PJ, Broadfield L, Power LA: Surface contamination with antineoplastic agents in six cancer treatment centers in Canada and the United States. Am J Health Syst Pharm 1999, 56:1427-1432.

13. Larson RR, Khazaeli MB, Dillon HK: Monitoring method for surface contamination caused by selected antineoplastic agents. Am J Health Syst Pharm 2002, 59:270-277.

14. Ziegler E, Mason HJ, Baxter PJ: Occupational exposure to cytotoxic drugs in two UK oncology wards. Occupational and environmental medicine 2002, 59:608-612.

15. Connor TH, Sessink PJ, Harrison BR, Pretty JR, Peters BG, Alfaro RM, Bilos $A$, Beckmann G, Bing MR, Anderson LM, Dechristoforo R: Surface contamination of chemotherapy drug vials and evaluation of new vialcleaning techniques: results of three studies. Am J Health Syst Pharm 2005, 62:475-484.

16. Fransman W, Vermeulen $\mathrm{R}$, Kromhout $\mathrm{H}$ : Occupational dermal exposure to cyclophosphamide in Dutch hospitals: a pilot study. The Annals of occupational hygiene 2004, 48:237-244.

17. Sorsa $\mathrm{M}$, Anderson D: Monitoring of occupational exposure to cytostatic anticancer agents. Mutation research 1996, 355:253-261.

18. Sessink PJ, Van de Kerkhof MC, Anzion RB, Noordhoek J, Bos RP: Environmental contamination and assessment of exposure to antineoplastic agents by determination of cyclophosphamide in urine of exposed pharmacy technicians: is skin absorption an important exposure route? Archives of environmental health 1994, 49:165-169.

19. Ensslin AS, Stoll Y, Pethran A, Pfaller A, Rommelt H, Fruhmann G: Biological monitoring of cyclophosphamide and ifosfamide in urine of hospital personnel occupationally exposed to cytostatic drugs. Occupational and environmental medicine 1994, 51:229-233.

20. DeMeo MP, Merono S, DeBaille AD, Botta A, Laget M, Guiraud H, Dumenil G: Monitoring exposure of hospital personnel handling cytostatic drugs and contaminated materials. International archives of occupational and environmental health 1995, 66:363-368.

21. ASHP: ASHP (American Society of Hospital Pharmacists) guidelines on handling hazardous drugs. American journal of hospital pharmacy 2006, 63:1172-1193.

22. NIOSH: NIOSH Alert: Preventing Occupational Exposures to Antineoplastic and Other Hazardous Drugs in Health Care Settings. Book NIOSH Alert: Preventing Occupational Exposures to Antineoplastic and Other Hazardous Drugs in Health Care Settings (Editor ed.^eds.) City: National Institute for Occupational Safety and Health; 2004.

23. OSHA: OSHA Technical Manual. Hospital Investigations: Health Hazard Section VI. Book OSHA Technical Manual. Hospital Investigations: Health Hazard - Section VI. (Editor ed.^eds.) City: Occupational Safety and Health Administration, US Department of Labor, Washington, DC; 2000.

24. GURI: Provvedimento di Linee-Guida per la sicurezza e la salute dei lavoratori esposti a chemioterapici antiblastici in ambiente sanitario (Repertorio Atti No. 736). Book Provvedimento di Linee-Guida per la sicurezza e la salute dei lavoratori esposti a chemioterapici antiblastici in ambiente sanitario (Repertorio Atti No. 736) (Editor ed.^eds.) City 1999.

25. Keshava N, Ong TM: Occupational exposure to genotoxic agents. Mutation research 1999, 437:175-194.

26. IARC: Some Antineoplastic and Immunosuppressive Agents Lyon (France): International Agency for Research on Cancer; 1981.

27. IARC: Overall Evaluations of Carcinogenicity: An Updating of IARC Monographs Volumes 1 to 42 Lyon (France): International Agency for Research on Cancer; 1987.

28. IARC: Pharmaceutical Drugs Lyon (France): International Agency for Research on Cancer; 1990.

29. IARC: Some antiviral and antineoplastic drugs, and other pharmaceutical agents Lyon (France): International Agency for Research on Cancer; 2000.

30. Skov T, Maarup B, Olsen J, Rorth M, Winthereik H, Lynge E: Leukaemia and reproductive outcome among nurses handling antineoplastic drugs. British journal of industrial medicine 1992, 49:855-861.

31. Gunnarsdottir HK, Aspelund T, Karlsson T, Rafnsson W: Occupational Risk Factors for Breast Cancer among Nurses. International journal of occupational and environmental health 1997, 3:254-258.

32. Ratner PA, Spinelli JJ, Beking K, Lorenzi M, Chow Y, Teschke K, Le ND, Gallagher RP, Dimich-Ward H: Cancer incidence and adverse pregnancy outcome in registered nurses potentially exposed to antineoplastic drugs. BMC nursing 2010, 9:15. 
33. Undeger U, Basaran N, Kars A, Guc D: Assessment of DNA damage in nurses handling antineoplastic drugs by the alkaline COMET assay. Mutation research 1999, 439:277-285.

34. Gebhart E, Losing J, Wopfner F: Chromosome studies on lymphocytes of patients under cytostatic therapy. I. Conventional chromosome studies in cytostatic interval therapy. Human genetics 1980, 55:53-63.

35. Gebhart E, Windolph B, Wopfner F: Chromosome studies on lymphocytes of patients under cytostatic therapy. II. Studies Using the BUDR-labelling technique in cytostatic interval therapy. Human genetics 1980, 56:157-167.

36. Aronson MM, Miller RC, Hill RB, Nichols WW, Meadows AT: Acute and longterm cytogenetic effects of treatment in childhood cancer: sisterchromatid exchanges and chromosome aberrations. Mutation research 1982, 92:291-307.

37. Carbonell E, Demopoulos NA, Stefanou G, Psaraki K, Parry KM, Marcos R: Cytogenetic analysis in peripheral lymphocytes of cancer patients treated with cytostatic drugs: results from an EC Collaborative Study. Anti-cancer drugs 1996, 7:514-519.

38. Norppa H, Sorsa M, Vainio H, Grohn P, Heinonen E, Holsti L, Nordman E: Increased sister chromatid exchange frequencies in lymphocytes of nurses handling cytostatic drugs. Scandinavian journal of work, environment \& health 1980, 6:299-301.

39. Nikula E, Kiviniitty K, Leisti J, Taskinen PJ: Chromosome aberrations in lymphocytes of nurses handling cytostatic agents. Scandinavian journal of work, environment \& health 1984, 10:71-74

40. Oestreicher U, Stephan G, Glatzel M: Chromosome and SCE analysis in peripheral lymphocytes of persons occupationally exposed to cytostatic drugs handled with and without use of safety covers. Mutation research 1990, 242:271-277

41. Sardas S, Gok S, Karakaya AE: Sister chromatid exchanges in lymphocytes of nurses handling antineoplastic drugs. Toxicology letters 1991, 55:311-315.

42. Goloni-Bertollo EM, Tajara EH, Manzato AJ, Varella-Garcia M: Sister chromatid exchanges and chromosome aberrations in lymphocytes of nurses handling antineoplastic drugs. International journal of cancer 1992, 50:341-344.

43. Anwar WA: Assessment of cytogenetic changes in human populations at risk in Egypt. Mutation research 1994, 313:183-191.

44. Kolmodin-Hedman B, Hartvig P, Sorsa M, Falck K: Occupational handling of cytostatic drugs. Archives of toxicology 1983, 54:25-33.

45. Barale R, Sozzi G, Toniolo P, Borghi O, Reali D, Loprieno N, Della Porta G: Sister-chromatid exchanges in lymphocytes and mutagenicity in urine of nurses handling cytostatic drugs. Mutation research 1985, 157:235-240.

46. Sorsa M, Pyy L, Salomaa S, Nylund L, Yager JW: Biological and environmental monitoring of occupational exposure to cyclophosphamide in industry and hospitals. Mutation research 1988 , 204:465-479.

47. Cooke J, Williams J, Morgan RJ, Cooke P, Calvert RT: Use of cytogenetic methods to determine mutagenic changes in the blood of pharmacy personnel and nurses who handle cytotoxic agents. American journal of hospital pharmacy 1991, 48:1199-1205.

48. Jakab MG, Major J, Tompa A: Follow-up genotoxicological monitoring of nurses handling antineoplastic drugs. Journal of toxicology and environmental health 2001, 62:307-318.

49. Kevekordes S, Gebel TW, Hellwig M, Dames W Dunkelberg H: Human effect monitoring in cases of occupational exposure to antineoplastic drugs: a method comparison. Occupational and environmental medicine 1998, 55:145-149.

50. Kasuba V, Rozgaj R, Garaj-Vrhovac V: Analysis of sister chromatid exchange and micronuclei in peripheral blood lymphocytes of nurses handling cytostatic drugs. J Appl Toxicol 1999, 19:401-404

51. Pilger A, Kohler I, Stettner H, Mader RM, Rizovski B, Terkola R, Diem E, FranzHainzl E, Konnaris C, Valic E, Rudiger HW: Long-term monitoring of sister chromatid exchanges and micronucleus frequencies in pharmacy personnel occupationally exposed to cytostatic drugs. International archives of occupational and environmental health 2000, 73:442-448.

52. Hessel H, Radon K, Pethran A, Maisch B, Grobmair S, Sautter I, Fruhmann G: The genotoxic risk of hospital, pharmacy and medical personnel occupationally exposed to cytostatic drugs-evaluation by the micronucleus assay. Mutation research 2001, 497:101-109.

53. Maluf SW, Erdtmann B: Follow-up study of the genetic damage in lymphocytes of pharmacists and nurses handling antineoplastic drugs evaluated by cytokinesis-block micronuclei analysis and single cell gel electrophoresis assay. Mutation research 2000, 471:21-27.

54. Pavanello S: Biomarkers of Toxicant Susceptibility. In Toxicologic Biomarkers. Edited by: DeCaprio AP. New York: Marcel-Dekker; 2006:

55. Musak L, Vodicka P, Klimentova G, Soucek P, Hanova M, Mikulkova R, Buchancova J, Vodickova L, Polakova V, Pec M: Chromosomal damage and polymorphisms of DNA repair genes XRCC1 and XRCC3 in workers exposed to cytostatics. Neuro endocrinology letters 2006, 27(Suppl 2):57-60.

56. Testa A, Giachelia M, Palma S, Appolloni M, Padua L, Tranfo G, Spagnoli M, Tirindelli D, Cozzi R: Occupational exposure to antineoplastic agents induces a high level of chromosome damage. Lack of an effect of GST polymorphisms. Toxicology and applied pharmacology 2007, 223:46-55.

57. Villarini M, Dominici L, Piccinini R, Fatigoni C, Ambrogi M, Curti G, Morucci P, Muzi G, Monarca S, Moretti M: Assessment of primary, oxidative and excision repaired DNA damage in hospital personnel handling antineoplastic drugs. Mutagenesis

58. Bonassi S, Norppa H, Ceppi M, Strömberg U, Vermeulen R, Znaor A, Cebulska-Wasilewska A, Fabianova E, Fucic A, Gundy S, Hansteen IL, Knudsen LE, Lazutka J, Rossner P, Sram RJ, Boffetta P: Chromosomal aberration frequency in lymphocytes predicts the risk of cancer: results from a pooled cohort study of 22358 subjects in 11 countries. Carcinogenesis 2008, 29:1178-1183.

59. Bonassi S, Znaor A, Ceppi M, Lando C, Chang WP, Holland N, KirschVolders M, Zeiger E, Ban S, Barale R, Bigatti MP, Bolognesi C, CebulskaWasilewska A, Fabianova E, Fucic A, Hagmar L, Joksic G, Martelli A Migliore L, Mirkova E, Scarfi MR, Zijno A, Norppa H, Fenech M: An increased micronucleus frequency in peripheral blood lymphocytes predicts the risk of cancer in humans. Carcinogenesis 2007, 28:625-631.

60. Moretti M, Dell'Omo M, Villarini M, Pastorelli R, Muzi G, Airoldi L, Pasquini R: Primary DNA damage and genetic polymorphisms for CYP1A1, EPHX and GSTM1 in workers at a graphite electrode manufacturing plant. BMC public health 2007, 7:270.

61. Pavanello S, Pulliero A, Siwinska E, Mielzynska D, Clonfero E: Reduced nucleotide excision repair and GSTM1-null genotypes influence anti-B[a] PDE-DNA adduct levels in mononuclear white blood cells of highly PAHexposed coke oven workers. Carcinogenesis 2005, 26:169-175.

62. Villarini M, Moretti M, Fatigoni C, Agea E, Dominici L, Mattioli A, Volpi R, Pasquini R: Evaluation of primary DNA damage, cytogenetic biomarkers and genetic polymorphisms for CYP1A1 and GSTM1 in road tunnel construction workers. Journal of toxicology and environmental health 2008, 71:1430-1439

63. Pavanello MB, Prado FA, Balducci I, Brandao AA, Almeida JD: Cytologic analysis of alterations induced by Smoking and by alcohol consumption. Acta cytologica 2006, 50:435-440.

64. Sessink PJ, Anzion RB, Van den Broek PH, Bos RP: Detection of contamination with antineoplastic agents in a hospital pharmacy department. Pharmaceutisch weekblad 1992, 14:16-22.

65. Carrieri M, Scapellato ML, Maccà I, Zoppellaro E, Salamon F, Cavedon F, Bartolucci GB: Determinazione della ciclofosfamide su superfici e nelle urine mediante gas cromatografia-spettrometria di massa. Folia Medica 2000, 71:201-204

66. Barbieri A, Nucci MC, Sabatini L, Risi A, Bolognesi C, Colacci A, Violante FS: [Occupational exposure to antineoplastic drugs in a hospital setting: biological and environmental monitoring]. Epidemiologia e prevenzione 2005, 29:87-90.

67. Sabatini L, Barbieri A, Tosi M, Roda A, Violante FS: A method for routine quantitation of urinary 8-hydroxy-2'-deoxyguanosine based on solidphase extraction and micro-high-performance liquid chromatography/ electrospray ionization tandem mass spectrometry. Rapid Commun Mass Spectrom 2005, 19:147-152.

68. Singh NP, McCoy MT, Tice RR, Schneider EL: A simple technique for quantitation of low levels of DNA damage in individual cells. Experimental cell research 1988, 175:184-191.

69. Tice RR, Agurell E, Anderson D, Burlinson B, Hartmann A, Kobayashi H, Miyamae Y, Rojas E, Ryu JC, Sasaki YF: Single cell gel/comet assay: guidelines for in vitro and in vivo genetic toxicology testing. Environmental and molecular mutagenesis 2000, 35:206-221.

70. Moretti M, Villarini M, Scassellati-Sforzolini G, Monarca S, Libraro M, Fatigoni C, Donato F, Leonardis C, Perego L: Biological monitoring of genotoxic hazard in workers of the rubber industry. Environmental health perspectives 1996, 104(Suppl 3):543-545. 
71. Moretti M, Villarini M, Scassellati-Sforzolini G, Monarca S, Salucci A, Rodriguez AV: Application of the single-cell gel-electrophoresis (" comet") assay to the detection of primary DNA damage in workers of the rubber industry: Comparison of manual and computerized analysis. Toxicological and Environmental Chemistry 1999, 72:13-24.

72. Moretti M, Villarini M, Sforzolini GS, Pasquini R: Pesticide-induced primary DNA damage in peripheral blood leukocytes of farm workers evaluated by the computerizedcomet'assay. Biomarkers 2000, 5:192-204.

73. Villarini M, Scassellati-Sforzolini G, Moretti M, Pasquini R: In vitro genotoxicity of terbutryn evaluated by the alkaline single-cell microgelelectrophoresis "comet" assay. Cell Biol Toxicol 2000, 16:285-292.

74. Collins AR, Duthie SJ, Dobson VL: Direct enzymic detection of endogenous oxidative base damage in human lymphocyte DNA. Carcinogenesis 1993, 14:1733-1735.

75. Boiteux S, Gajewski E, Laval J, Dizdaroglu M: Substrate specificity of the Escherichia coli Fpg protein (formamidopyrimidine-DNA glycosylase): excision of purine lesions in DNA produced by ionizing radiation or photosensitization. Biochemistry 1992, 31:106-110.

76. Doetsch PW, Henner WD, Cunningham RP, Toney JH, Helland DE: A highly conserved endonuclease activity present in Escherichia coli, bovine, and human cells recognizes oxidative DNA damage at sites of pyrimidines. Molecular and cellular biology 1987, 7:26-32.

77. Crebelli R, Carta P, Andreoli C, Aru G, Dobrowolny G, Rossi S, Zijno A: Biomonitoring of primary aluminium industry workers: detection of micronuclei and repairable DNA lesions by alkaline SCGE. Mutation research 2002, 516:63-70.

78. Andreoli C, Leopardi P, Rossi S, Crebelli R: Processing of DNA damage induced by hydrogen peroxide and methyl methanesulfonate in human lymphocytes: analysis by alkaline single cell gel electrophoresis and cytogenetic methods. Mutagenesis 1999, 14:497-504.

79. Fenech $\mathrm{M}$ : The in vitro micronucleus technique. Mutation research 2000, 455:81-95

80. Fenech M, Holland N, Chang WP, Zeiger E, Bonassi S: The HUman MicroNucleus Project-An international collaborative study on the use of the micronucleus technique for measuring DNA damage in humans. Mutation research 1999, 428:271-283.

81. Fenech M, Chang WP, Kirsch-Volders M, Holland N, Bonassi S, Zeiger E: HUMN project: detailed description of the scoring criteria for the cytokinesis-block micronucleus assay using isolated human lymphocyte cultures. Mutation research 2003, 534:65-75.

82. IAEA: Cytogenetic Analysis for Radiation Dose Assessment. Book Cytogenetic Analysis for Radiation Dose Assessment (Editor ed.^eds.) City: International Atomic Energy Agency; 2001.

83. Savage JR, Holloway M: Induction of sister-chromatid exchanges by $\mathrm{d}(42$ $\mathrm{MeV}$ )-Be neutrons in unstimulated human-blood lymphocytes. The British journal of radiology 1988, 61:231-234.

84. Pavanello S, Kapka L, Siwinska E, Mielzyñska D, Bolognesi C, Clonfero E: Micronuclei related to anti-B[a]PDE-DNA adduct in peripheral blood lymphocytes of heavily polycyclic aromatic hydrocarbon-exposed nonsmoking coke-oven workers and controls. Cancer Epidemiol Biomarkers Prev 2008, 17:2795-9.

85. Pavanello S, Simioli P, Lupi S, Gregorio P, Clonfero E: Exposure levels and cytochrome P450 $1 \mathrm{~A} 2$ activity, but not $\mathrm{N}$-acetyltransferase, glutathione S-transferase (GST) M1 and T1, influence urinary mutagen excretion in smokers. Cancer Epidemiol Biomarkers Prev 2002, 11:998-1003.

\section{Pre-publication history}

The pre-publication history for this paper can be accessed here: http://www.biomedcentral.com/1471-2458/11/195/prepub

doi:10.1186/1471-2458-11-195

Cite this article as: Moretti et al:: A study protocol for the evaluation of occupational mutagenic/carcinogenic risks in subjects exposed to antineoplastic drugs: a multicentric project. BMC Public Health 2011 11:195.

\section{Submit your next manuscript to BioMed Central and take full advantage of:}

- Convenient online submission

- Thorough peer review

- No space constraints or color figure charges

- Immediate publication on acceptance

- Inclusion in PubMed, CAS, Scopus and Google Scholar

- Research which is freely available for redistribution

Submit your manuscript at www.biomedcentral.com/submit
Biomed Central 